\title{
MENINGKATKAN HASIL BELAJAR SISWA MELALUI MODEL PEMBELAJARAN KOOPERATIF TIPE JIGSA $W$ DI KELAS IV SD NEGERI 2 BATUGANDA
}

\author{
Mustari', Yoo Eka Yana Kansil ${ }^{2)}$ \\ 1) SDN 2 Batuganda, Kolaka Utara, Indonesia \\ ${ }^{2)}$ Jurusan PGSD, Universitas Halu Oleo, Kendari, Indonesia \\ email: mus@yahoo.com
}

\begin{abstract}
Abstrak: Penelitian ini bertujuan untuk meningkatkan hasil belajar siswa pada materi pokok KPK dan FPB di kelas IV SD Negeri 2 Batuganda melalui model pembelajaran kooperatif tipe jigsaw. Adapun prosedur penelitian ini terdiri atas: perencanaan, pelaksanaan tindakan siklus, observasi dan evaluasi, dan refleksi. Data yang diperoleh dalam penelitian ini adalah data kuantitatif dan data kualitatif. Data kualitatif diambil dengan menggunakan lembar observasi sedangkan data kuantitatif diambil dari tes hasil belajar. Berdasarkan hasil analisis dan pembahasan, hasil belajar siswa mengalami peningkatan, sebagaimana pada tindakan siklus I ketuntasan hasil belajar siswa mencapai 37,04\% dengan nilai ratarata 61,48. Sedangkan pada siklus II ketuntasan hasil belajar siswa mencapai $85,19 \%$ dengan nilai rata-rata 82,96. Kesimpulan dari penelitian adalah aktivitas siswa pada siklus I pertemuan ke-1 72,5\%, pada pertemuan ke-2 77,5\% pada siklus II pertemuan ke-1 $85 \%$ dan pertemuan ke-2 90\%, sedangkan aktivitas guru dalam KBM pada siklus I pertemuan ke-1 $77,6 \%$, pertemuan ke-2 $84,2 \%$, pada siklus II pertemuanke-1 $94,7 \%$ pada peertemuan ke-2 mencapai 97,4\% dan hasil belajar siswa pada siklus I mencapai 37,04 \% dan pada siklus II meningkat menjadi 85, 19 $\%$.
\end{abstract}

Kata kunci: model pembelajaran; jigsaw; hasil belajar

\section{IMPROVING STUDENTS' LEARNING OUTCOMES THROUGH THE JIGSAW TYPE COOPERATIVE LEARNING MODEL AT CLASS IV OF SD NEGERI 2 BATUGANDA}

Abstract: This study aimed to improve students' learning outcomes on the subject matter of KPK and FPB at Class IV of SD Negeri 2 Batuganda through the jigsaw type cooperative learning model. The research procedure was consisted of planning, implementing cycle actions, observation and evaluation, and reflection. The data obtained in this research were quantitative data and qualitative data. Qualitative data were taken using observation sheets, while quantitative data were taken from learning outcomes tests. Based on the results of the analysis and discussion, students' learning outcomes have increased, as in the first cycle action completeness of students' learning outcomes reached $37.04 \%$ with an average value was 61.48. Whereas in cycle II, the completeness of students' learning outcomes reached $85.19 \%$ with an average value was 82.96 . The conclusion of the research was that students' activity in the first cycle of the first meeting was $72.5 \%$, at the second meeting was $77.5 \%$. In the second cycle at the first meeting was $85 \%$ and the second meeting was 90\%, while the teacher's activities in teaching and learning activities at the first cycle of the first meeting was $77.6 \%$ and at the second meeting was $84.2 \%$. In the second cycle at the first meeting was $94.7 \%$ and at the second meeting it reached $97.4 \%$. Students' learning outcomes in the first cycle reached 37, 04\% and in cycle II increased to 85, $19 \%$.

Keywords: learning model, Jigsaw, learning outcomes 


\section{Pendahuluan}

Salah satu diantara masalah besar dalam bidang pendidikan di Indonesia yang banyak diperbincangkan adalah rendahnya mutu pendidikan yang tercermin dari rendahnya rata-rata hasil belajar. Masalah lain dalam pendidikan di Indonesia yang juga banyak diperbincangkan adalah bahwa pendekatan dalam pembelajaran masih terlalu didominasi peran guru. Guru banyak menempatkan siswa sebagai obyek dan bukan sebagai subyek didik. Pendidikan kita kurang memberikan kesempatan pada siswa dalam berbagai mata pelajaran untuk mengembangkan kemampuan berpikir holistik (menyeluruh), kreatif, objektif, dan logis. Belum memanfaatkan quantum learning sebagai salah satu paradigma menarik dalam pembelajaran, serta kurang memperhatikan keberhasilan belajar secara individual.

Belajar dan mengajar merupakan dua konsep yang tidak bisa dipisahkan satu sama lain. Belajar menunjukkan kepada apa yang harus dilakukan seseorang sebagai penerima pelajaran (siswa), sedangkan mengajar menunjukkan kepada apa yang harus dilakukan oleh seorang guru yang menjadi pengajar. Jadi belajar mengajar merupakan proses interaksi antara guru dan siswa pada saat proses pengajaran. Belajar adalah suatu proses usaha yang dilakukan seseorang untuk memperoleh suatu perubahan tingkah laku yang baik secara keseluruhan, sebagai hasil pengalamannya sendiri dalam interaksi dengan lingkungannya. (Slameto, 2003, p.2). Proses pengajaran akan berhasil selain ditentukan oleh kemampuan guru dalam menentukan metode dan alat yang digunakan dalam pengajaran, juga ditentukan oleh minat belajar siswa.

Rendahnya hasil belajar siswa dikarenakan guru dalam menerangkan materi matematika kurang jelas dan kurang menarik perhatian siswa dan pada umumnya guru terlalu cepat dalam menerangkan materi pelajaran. Di samping itu penggunaan metode pengajaran yang salah. Sehingga siswa dalam memahami dan menguasai materi masih kurang dan nilai yang diperoleh siswa cenderung rendah. Berdasarkan pengalaman dan refleksi di kelas kelemahan belajar matematika di kelas IV SD Negeri 2 Batuganda adalah bahwa selama proses pembelajaran, guru belum memberdayakan potensi siswa sehingga sebagian besar belum mampu mencapai kompetensi individual yang diharapkan dalam kurikulum. Beberapa siswa belum belajar pada tingkat pemahaman. Siswa baru mampu menghafal fakta, konsepkonsep, hukum teori dan gagasan pada tingkat ingatan. Mereka belum dapat menggunakan dan menerapkannya dalam memecahkan masalah-masalah sehari-hari. "The properties of the domain and the subject area have undergone various modifications in terms of the duration of the group work (a unit or a single topic), teaching materials used, activities, assessment processes, the organization of the groups, the approaches of creating dependency, giving responsibility, providing motivation approaches, and reward structures" (Buhr, dkk, 2014, p.430).

Masalah-masalah di atas merupakan masalah-masalah pendekatan pembelajaran, belum lagi masalah-masalah dari siswa itu sendiri. Terutama pada pelajaran matematika, mengingat pelajaran matematika merupakan mata pelajaran yang terkenal sulit dan memerlukan logika berpikir yang tinggi, selain itu juga dikhawatirkan aktivitas belajar matematika terganggu, jika suasana pembelajaran matematika tidak menyenangkan.

Upaya membangkitkan minat dan meningkatkan hasil belajar siswa kelas IV SD Negeri 2 Batuganda dalam pembelajaran matematika sudah dilakukan guru di kelas dengan berbagai strategi, seperti memberi kesempatan kepada siswa untuk bertanya dan mengungkapkan gagasan, serta mendesain pembelajaran dalam bentuk demonstrasi. Dengan hasil rata-rata ulangan harian mata pelajaran matematika khususnya materi KPK dan FPB tahun pelajaran 2014/2015 pada materi KPK dan FPB adalah 55 dimana KKM yang ditetapkan sekolah yaitu 60, pada tahun pelajaran 2015/1016 pada materi KPK dan FPB adalah 58 dimana KKM sekolah mata pelajaran matematika yaitu 62. Rata-rata nilai ulangan 
harian matematika dari 27 siswa belum mencapai ketuntasan. Dimana Kriteria Ketuntasan Minimal (KKM) mata pelajaran matematika SD Negeri 2 Batuganda adalah 65.

Model mengajar mempunyai karakteristik tertentu dengan segala kelebihan dan kelemahan masing-masing maka keberhasilan belajar bergantung pada ketepatan pemilihan model dalam arti kesesuaian antara tujuan pokok dengan model, situasi dan kondisi serta kepribadian guru yang mengajarkan materi itu" (Depdiknas, 2005, p.9). Dalam kurikulum matematika diharapkan dapat membangkitkan kreativitas siswa agar siswa tersebut belajar aktif, dimungkinkan konsep-konsep matematika yang dijarkan sudah dipahami denga baik. Oleh sebab itu dalam memilih model mengajar, guru sedapat mungkin mengacu pada cara belajar siswa aktif sehingga diharapkan model mengajar yang digunakan lebih efektif. Untuk dapat mengarahkan siswa sehingga dapat belajar aktif dalam pembelajaran, maka alternatif solusi peniliti tawarkan adalah dengan menrapkan model pembelajaran kooperatif tipe jigsaw pada pembelajaran matematika. Alasan peneliti menawarkan model pembelajaran kooperatif tipe jigsaw sebagai alternatif solusi atas permasalahan yang dihadapi di SD Negeri 2 Batuganda karena melalui model pembelajaran ini diharapkan dapat membangkitkan kreativitas siswa dan siswa dapat belajar lebih aktif sebab siswa lebih bayak berperan secara berkelompok dalam pembelajaran. Dengan menerapkan model pembelajaran ini maka diharapkan hasil belajar siswa SD Negeri 2 Batuganda akan meningkat.

Model pembelajaran kooperatif tipe jigsaw merupakan salah satu model mengajar yang dapat diterapkan oleh guru di SD Negeri 2 Batuganda untuk mengatasi masalah dalam proses belajar mengajar. Melalui model ini siswa dalam mempelajari materi pelajaran yang dimodelkan atau dipersentasikan lebih dahulu oleh guru secara tahap demi tahap dan terstruktur mulai dari materi yang sifatnya sederhana menuju ke materi yang sifatnya lebih kompleks. Agar setiap siswa dapat menyelesaikan masalah pada konsep yang kompleks maka diberikan pelatihan lanjutan namun masih berada dibawah bimbingan guru. Slavin (2008, p.237) menyatakan bahwa " Pembelajaran kooperatif Jigsaw menjadikan siswa termotivasi untuk belajar karena skor-skor yang dikontribusikan siswa kepada tim didasarkan pada sistem skor perkembangan individual, dan siswa yang skor timnya meraih skor tertinggi akan menerima sertifikat atau bentuk-bentuk rekognisi tim yang lain sehingga siswa termotivasi untuk mempelajari materi dengan baik dan untuk bekerja keras serta aktif dalam kelompok ahli supaya dapat membantu tim melakukan tugas dengan baik". Tiap individu memberi kontribusi pada pencapaian tujuan anggota yang lain pada pembelajaran kooperatif tipe Jigsaw. Tiap anggota kelompok bisa meraih tujuan pribadi jika kelompok sukses sehingga untuk meraih tujuan pribadinya, anggota kelompok harus membantu teman satu tim untuk melakukan apapun guna membuat kelompok berhasil, dan yang lebih penting adalah mendorong anggota satu kelompok untuk melakukan usaha maksimal. Setiap anggota kelompok memotivasi anggota kelompok lain. Alfazr, dkk. (2016, p.113) model pembelajaran jigsaw ini bisa menjadi alternatif pemecahan masalah dengan langkah-langkah pembelajarannya yang sangat efektif dibandingkan dengan pembelajaran yang hanya menggunakan metode konvensional saja.

Berdasarkan uraian di atas terkait masih rendahnya hasil belajar matematika siswa kelas IV SD Negeri 2 Batuganda maka penulis berupaya ingin menerapkan model pembelajaran kooperatif tipe jigsaw dengan judul "Meningkatkan Hasil Belajar Siswa pada Materi KPK dan FPB Melalui Model Pembelajaran Kooperatif Tipe Jigsaw di Kelas IV SD Negeri 2 Batuganda". Dengan menggunakan model pembelajaran ini diasumsikan dapat meningkatkan hasil belajar siswa kelas IV SD Negeri 2 Batuganda pada materi KPK dan FPB.

Masalah dalam penelitian ini adalah: Apakah hasil belajar siswa pada materi KPK dan FPB di kelas IV SD Negeri 2 Batuganda dapat ditingkatkan melalui model pembelajaran 
kooperatif tipe jigsaw? Tujuan penelitian ini adalah untuk meningkatkan hasil belajar siswa pada materi KPK dan FPB di kelas IV SD Negeri 2 Batuganda melalui model pembelajaran kooperatif tipe jigsaw. Penelitian ini diharapkan dapat memberikan manfaat bagi guru, siswa, sekolah dan penelitian lainnya.

\section{Metode}

Jenis penelitian adalah penelitian tindakan kelas (PTK. dilaksanakan di Kelas IV SD Negeri 2 Batuganda Kolaka Utara semester ganjil tahun pelajaran 2016/2017 dengan subyek dalam penelitian ini adalah siswa kelas IV SD Negeri 2 Batuganda Kolaka Utara Kabupaten Kolaka Utara yang mengikuti mata pelajaran matematika dengan materi pokok operasi hitung campuran bilangan bulat tahun ajaran 2016/2017 sebanyak 27. Penelitian tindakan kelas ini dilaksanakan dalam dua siklus yang terdiri dari empat tahapan yaitu perencanaan, pelaksanaan tindakan, observasi dan evaluasi serta refleksi Jenis data dalam penelitian ini adalah data kualitatif dan kuantitatif. Data kualitatif berupa kegiatan proses pembelajaran aktivitas belajar siswa dan aktivitas guru. Data kuantitatif berupa nilai hasil belajar siswa. Sumber data dalam penelitian ini adalah guru dan siswa Kelas IV SD Negeri 2 Batuganda Kolaka Utara.

Data kualitatif akan dianalisis secara deskriptif kualitatif berdasarkan observasi, sedangkan data kuantitatif dianalisis secara kuantitatif menggunakan rumus:

1. Untuk menghitung persentase ketuntasan pelaksanaan pembelajaran :

$$
\text { Keterlaksanaan } R P P=\frac{\text { Jumlah skor aspek yang terlaksana }}{\text { Jumlah skor maksimal aspek observasi }} \times 100 \%
$$

2. Untuk menghitung persentase aktivitas belajar siswa :

persentase aktivitas belajar siswa $=\frac{\text { Jumlah } \text { skor perolehan }}{\text { Jumlah } \text { skor } \text { maksimal }} \times 100 \%$

3. Untuk menghitung rerata hasil belajar siswa :

$$
\bar{x}=\frac{\sum x i}{n}
$$

4. Menghitung tingkat pencapaian ketuntasan belajar :

Secara individual \% TB $=\frac{\text { Nilai yang dicapai }}{\text { Nilai ideal }} \times 100 \%$

5. Menentukan persentase ketuntasan :

$$
\% \mathrm{~TB}=\frac{\sum T B}{n} \times 100 \%
$$

Indikator dalam penelitian ini adalah dilihat dari dua segi yaitu segi proses dan segi hasil. Dari proses dikatakan berhasil apabila minimal 90\% skenario pembelajaran terlaksana dengan baik, sedangkan dari segi hasil belajar minimal 80\% siswa memperoleh nilai $\geq 65$ (sesuai dengan KKM sekolah).

\section{Hasil}

\section{Hasil Belajar Siswa}

Hasil evaluasi tes yang dilakukan pada siklus I pertemuan ke-2 menunjukkan bahwa pemahaman siswa terhadap materi tentang KPK dan FPB adanya peningkatan bila dibandingkan dengan hasil evaluasi pada siklus I pertemuan ke-1. Terdapat sekitar 37,04\% atau sebanyak 10 siswa telah menguasai materi pada siklus I dan mengalami peningkatan jika dibandingkan dengan hasil ulangan harian tahun lalu yaitu 26,67\% atau sebanyak 8 siswa yang memahami tentang materi ini. Walapun terjadi peningkatan, namun peningkatan tersebut belum mencapai KKM yang telah ditentukan sekolah yaitu 65. Dari soal-soal evaluasi tersebut, maka pada pelaksanaan tindakan siklus II ini hasil belajar siswa menunjukkan bahwa 
terdapat $85,19 \%$ siswa telah menguasai materi yang telah diajarkan, ini berarti memperlihatkan terjadi peningkatan $48,15 \%$ dari pelaksanaan tindakan siklus I.

\section{Aktivitas Mengajar Guru}

Hasil analisis pengamatan aktivitas guru selama pembelajaran berlangsung pada siklus I pertemuan ke-1 dengan skor maksimal 76, skor perolehan 59, persentase keterlaksanaan RPP adalah 77,6\% diolah dari skor perolehan dibagi skor maksimal dikali dengan $100 \%$ sehingga mendapatkan $77,6 \%$ dan pada siklus I pertemuan ke-2 skor maksimal 76 skor perolehan 64, persentase keterlaksanaan RPP 84,2\%. Hasil analisis pengamatan aktivitas guru selama pembelajaran berlangsung pada siklus II pertemuan ke-1 dengan skor maksimal 76, skor perolehan 72, persentase keterlaksanaan RPP adalah 94,7\% diolah dari skor perolehan dibagi skor maksimal dikali dengan $100 \%$ sehingga mendapatkan $94,7 \%$ dan pada siklus II pertemuan ke-2 skor maksimal 76 skor perolehan 74, persentase keterlaksanaan RPP $97,4 \%$.

\section{Aktivitas Belajar Siswa}

Hasil analisis pengamatan aktivitas belajar siswa pada siklus I pertemuan ke-1 dengan skor maksimal 40 dan skor perolehan 29 maka persentanse aktivitas siswa pada siklus I pertemuan ke-1 ini adalah skor perolehan dibagi skor maksimal dikali dengan $100 \%$, jadi persentase aktivitas belajar siswa adalah $72,5 \%$. Dan pada siklus I pertemuan ke-2 dengan skor maksimal 40, skor perolehan 31, persentase aktivitas belajar siswa 77,5\% diolah dari skor perolehan bagi skor maksimal dikali $100 \%$. Hasil analisis pengamatan aktivitas belajar siswa pada siklus II pertemuan ke-1 dengan skor maksimal 40 dan skor perolehan 31 maka persentanse aktivitas siswa pada siklus II pertemuan ke-1 ini adalah skor perolehan dibagi skor maksimal dikali dengan $100 \%$, jadi persentase aktivitas belajar siswa adalah $85 \%$. Dan pada siklus II pertemuan ke-2 dengan skor maksimal 40, skor perolehan 36, persentase aktivitas belajar siswa $90 \%$ diolah dari skor perolehan bagi skor maksimal dikali $100 \%$.

\section{Pembahasan}

Berdasarkan hasil analisis data terhadap aktivitas belajar siswa pada siklus I bahwa aktivitas belajar siswa adalah masih belum efektif. Ini menunjukkan bahwa penerapan model pembelajaran kooperatif tipe Jigsaw belum terlaksana dengan baik dan masih terdapat beberapa kekurangan seperti; ada sebagian siswa kurang cermat dalam melakukan pengamatan pada LKS yang diberikan guru, ada beberapa siswa masih kurang aktif dalam mempresentasikan hasil diskusi kelompoknya serta kurangnya kepercayaan diri dari siswa untuk menghargai/menerima pendapat teman kelompoknya karena sebagian siswa tersebut lebih asik bermain dan bercerita. Beberapa kekurangan itu kemudian direfleksi dan dilakukan beberapa perbaikan untuk pelaksanaan tindakan pada siklus II.

Berdasarkan hasil analisis data terhadap aktivitas guru pada siklus I menunjukkan bahwa aktivitas guru dalam proses pembelajaran sudah cukup baik, dimana guru dianggap sudah bisa melaksanakan kegiatan belajar mengajar sesuai dengan skenario pembelajaran, walaupun masih ada beberapa kekurangan dalam pelaksanaannya, seperti keterampilan guru untuk mengkoordinasi siswa ke dalam kelompok heterogen masih kurang baik dan menyimpulkan tujuan pembelajaran serta antusias siswa masih kurang baik. Beberapa kekurangan ini terjadi karena guru masih kaku dalam menggunakan model pembelajaran kooperatif tipe Jigsaw.

Beberapa kekurangan pada siklus I kemudian direfleksi dan dilakukan perbaikanperbaikan untuk pelaksanaan tindakan pada siklus II. Hasil refleksi tersebut menjadi pedoman dalam pelaksanaan siklus II. Pada pelaksanaan tindakan siklus II terlihat kemajuan, hal ini 
dapat dilihat dari hasil analisis data terhadap aktivitas belajar siswa pada siklus II pertemuan ke-1 yaitu $72,5 \%$ pada pertemuan ke-2 yaitu $77,5 \%$ dan pada siklus II pertemuan ke-1 yaitu $85 \%$ dan ke-2 yaitu $90 \%$. Ini berarti bahwa aktivitas belajar siswa dari siklus I meningkat sangat baik berdasarkan kriteria keterlaksanaan walaupun masih ada yang kurang terutama dalam menghargai/menerima pendapat dimana siswa masih menganggap remeh jawaban temannya, meskipun demikian siswa sudah memahami model pembelajaran yang diterapkan.

Hal ini sejalan dengan pendapat Darsono (2000, p.24), menyatakan bahwa "Model pembelajaran kooperatif tipe Jigsaw adalah pembelajaran dimana siswa belajar dalam kelompok bertanggungjawab atas penguasaan materi belajar yang ditugaskan kepadanya lalu mengajarkan bagian tersebut pada anggota kelompok lain”. Jadi pembelajaran tipe Jigsaw ini merupakan bagian dari pembelajaran kooperatif yang merupakan pembelajaran kelompok dimana setiap anggota bertanggungjawab atas penguasaan materi tertentu dan mengajarkannya kepada anggota kelompoknya setelah mempelajari dengan kelompok ahli masing-masing. Senada dengan hal tersebut dengan pembentukan kelompok dalam pembelajaran yang dikemukakan oleh Arends (dalam Trianto 2010, p.65) menyatakan bahwa kelompok dibentuk dari siswa yang mempunyai kemampuan tinggi, sedang, dan rendah serta bila memungkinkan anggota kelompok berasal dari ras, budaya, suku dan jenis kelamin yang beragam.

Para anggota dari kelompok asal yang berbeda, bertemu dengan topik yang sama dalam kelompok ahli untuk berdiskusi dan membahas materi yang ditugaskan pada masingmasing anggota kelompok serta membantu satu sama lain untuk mempelajari topik mereka tersebut. Disini, peran guru adalah memfasilitasi dan memotivasi para anggota kelompok ahli agar mudah untuk memahami materi yang diberikan. Setelah pembahasan selesai, para anggota kelompok kemudian kembali pada kelompok asal dan mengajarkan pada teman sekelompoknya apa yang telah mereka dapatkan pada saat pertemuan di kelompok ahli. Para kelompok ahli harus mampu untuk membagi pengetahuan yang didapatkan saat melakukan diskusi di kelompok ahli, sehingga pengetahuan tersebut diterima oleh setiap anggota pada kelompok asal. Kunci tipe Jigsaw ini adalah setiap siswa bertanggung jawab terhadap anggota tim yang memberikan informasi yang diperlukan. Artinya para siswa harus memiliki tanggungjawab dan kerja sama yang positif dan saling ketergantungan untuk mendapatkan informasi dan memecahkan masalah yang diberikan. Menurut Sudjana dalam Rukmia (2015, p.289) "hasil belajar adalah kemampuan-kemampuan yang dimiliki siswa setelah Ia menerima pengalaman belajar ".

Berdasarkan hasil analisis data terhadap aktivitas guru pada siklus II menunjukkan bahwa aktivitas guru dalam proses pembelajaran sudah baik, dimana guru dianggap sudah bisa melaksanakan kegiatan belajar mengajar sesuai dengan skenario pembelajaran terlihat pada skor aktivitas guru yaitu pada siklus I pertemuan ke-1 yaitu 77,6\% dan pada pertemuan ke-2 yaitu $84,2 \%$ sedangkan pada siklus II pertemuan ke-1 yaitu 94,7\% dan pada pertemuan ke-2 yaitu 97,4\%. Hal ini menunjukkan bahwa aktivitas guru dalam pembelajaran sudah sangat baik sesuai dengan kriteria keterlaksanaan.

Berdasarkan hasil analisis data siklus I dan II, terlihat bahwa dengan menggunakan model pembelajaran kooperatif tipe Jigsaw dipandang cocok untuk digunakan dalam meningkatkan aktivitas belajar siswa pada materi sistem pencernaan makanan. Hal ini terjadi karena siswa sangat antusias dengan anggota kelompoknya. Penerapan model pembelajaran ini siswa diajar dan dibimbing untuk belajar kelompok, kerjasama, bertanggungjawab pada masing-masing keahliannya. Peningkatan aktivitas belajar siswa di tiap siklusnya menjadi gambaran bahwa siswa telah mampu meningkatkan kemampuan kognitifnya dalam hal ini pemahamannya tentang materi KPK dan FPB sudah baik, sehingga dapat dikatakan penelitian ini telah berhasil meningkatkan aktivitas belajar siswa dengan hasil yang memuaskan. Ismail 
\& Elias (2006, p.21) mengemukakan bahwa "In order to fully grasp the concept, learners must experience inquiry directly to gain a deep understanding of its characteristics." Hasil penelitian ini bila dikaitkan dengan teori masih relevan. Menurut Sagala (2010, p.87) hasil belajar dipengaruhi oleh beberapa faktor baik intern maupun ekstern.

Model pembelajaran kooperatif tipe Jigsaw adalah salah satu model pembelajaran yang didesain untuk meningkatkan rasa tanggungjawab siswa terhadap pembelajaranya sendiri dan juga pembelajaran orang lain. Siswa tidak hanya mempelajari materi yang diberikan, tetapi mereka juga harus siap memberikan materi tersebut kepada kelompoknya. Sehingga baik kemampuan secara kognitif maupun sosial siswa sangat dibutuhkannya.

\section{Simpulan}

Berdasarkan hasil analisis dan pembahasan pada bab sebelumnya disimpulkan bahwa hasil belajar siswa pada materi KPK dan FPB melalui model pembelajaran kooperatif Tipe Jigsaw di SD Negeri 2 Batuganda dapat ditingkatkan. Hal ini dapat dilihat pada peningkatan hasil belajar siswa pada siklus 1 yaitu $37,04 \%$ dan pada siklus 2 meningkat menjadi 85,19\%.

\section{Referensi}

Alfazr. A.S., Diah Gusrayani, \& Sunarya, D.T. (2016). Penerapan Model Pembelajaran Jigsaw Untuk Meningkatkan Hasil Belajar Siswa Dalam Menemukan Kalimat Utama Pada Tiap Paragraf. Jurnal Pena Ilmiah: Vol. 1, No. 1. 111-120. https://ejournal.upi.edu/index.php/penailmiah/article/download/2937/1965

Buhr, G. T., M. T. Heflin, H. K. White, S. O. (2014). Using the Jigsaw Cooperative Learning Method to Teach Medical Students About Long-Term and Postacute Care. Journal of the American Medical Directors Association, Volume.15, No.6, 429-434. http://dx.doi.org/10.1016/j.jamda.2014.01.015 Darsono. (2000). Belajar dan Pembelajaran. Semarang: IKIP Press.

Darsono. (2000). Belajar dan pembelajaran. Semarang: IKIP Semarang Press.

Departemen Pendidikan Nasional. (2005). Pelatihan Terintegrasi Berbasis Kompetensi Guru Mata Pelajaran Matematika (Model-Model Pembelajaran). Jakarta: Depdiknas.

Depdiknas. (2005). Panduan Pengembangan Model Pembelajaran Berbasis. Kompetensi. Jakarta: Direktorat PPTK dan KPT Dirjen Dikti.

Ismail, Noriah \& Elias, S. (2006). Inquiry-Based Learning: An Innovative Teaching Method Article. English Language Journal (2006) Vol.2(1): 13-24. UPSI Malaysia. https://www.researchgate.net/publication/259632827

Rukmia. (2016). Meningkatkan Hasil Belajar Siswa Melalui Model Pembelajaran Kooperatif Tipe Jigsaw Dalam Pembelajaran IPA Materi Pesawat Sederhana Di Kelas V SDN No. 1 Balukang II. Jurnal Kreatif Tadulako Online Vol. 4 No. 1, 287-295. http://jurnal.untad.ac.id/jurnal/index.php/JKTO/article/download/3292/2335

Sagala, Syaiful. (2010). Supervisi Pembelajaran dalam Profesi Pendidikan. Bandung: Alfabeta. 
Slameto. (2003). Belajar dan Faktor-Faktor yang Mempengaruhinya. Jakarta: Rineka Cipta

Slavin, R. (1995). Cooperative Learning: Theory, Research, and Practise. Boston: Allyand and Bacon Publishers.

Slavin, Robert E. (2008). Cooperative Learning. Bandung: Nusa Media.

Trianto. (2010). Mendesain Model Pembelajaran Inovatif-Progresif. Kharisma Putra Utama. Surabaya 